\title{
Sulfur Reduction in Gasoline and Diesel Fuels by Extraction/Adsorption of Refractory Dibenzothiophenes
}

\author{
Annual Technical Progress Report
}

September 1, 2000 - August 31, 2001

\author{
Robert J. Angelici \\ Principal Investigator \\ Scott G. McKinley and Celedonio Alvarez \\ Research Assistants
}

Issued October 2001

DOE Award No. DE-F626-OONT40820

\author{
Chemistry Department \\ 1605 Gilman Hall \\ Iowa State University \\ Ames, IA 50011-2230
}




\section{DISCLAIMER}

This report was prepared as an account of work sponsored by an agency of the United States Government. Neither the United Stated Government nor any agency thereof, nor any of their employees, makes any warranty, express or implied, or assumes any legal liability or responsibility for the accuracy, completeness, or usefulness of any information, apparatus, product, or process disclosed, or represents that its use would not infringe privately owned rights. Reference herein to any specific commercial product, process, or service by trade name, trademark, manufacturer, or otherwise does not necessarily constitute or imply its endorsement, recommendation, or favoring by the United States Government or any agency thereof. The views and opinions of the authors expressed herein do not necessarily state or reflect those of the United States Government or any agency thereof. 
Sulfur Reduction in Gasoline and Diesel Fuels by Extraction/Adsorption of

Refractory Dibenzothiophenes

\author{
Annual Technical Progress Report \\ September 1, 2000 - August 31, 2001
}

Robert J. Angelici

Principal Investigator

\begin{abstract}
$\underline{\text { ABSTRACT }}$
Using the classical coordination compound, $\mathrm{Ru}\left(\mathrm{NH}_{3}\right)_{5}\left(\mathrm{H}_{2} \mathrm{O}\right)^{2+}$, we have prepared a metal complex with a 4,6-dimethyldibenzothiophene ligand. The compound $\mathrm{Ru}\left(\mathrm{NH}_{3}\right)_{5}\left(\mathrm{H}_{2} \mathrm{O}\right)^{2+}$ also reacts with thiophene, benzothiophene and dibenzothiophene (DBT) at room temperature. We have found that $\mathrm{Ru}\left(\mathrm{NH}_{3}\right)_{5}\left(\mathrm{H}_{2} \mathrm{O}\right)^{2+}$ removes over $50 \%$ of the DBT in simulated petroleum feedstocks by a biphasic extraction process. The extraction phase is readily regenerated by air-oxidation thereby completing a cyclic process that removes DBT from petroleum feedstocks.
\end{abstract}




\section{TABLE OF CONTENTS}

DISCLAIMER

$\begin{array}{ll}\text { ABSTRACT } & 3\end{array}$

LIST OF GRAPHICAL MATERIAL

$\begin{array}{ll}\text { EXECUTIVE SUMMARY } & 8\end{array}$

$\begin{array}{ll}\text { INTRODUCTION } & 7\end{array}$

$\begin{array}{ll}\text { EXPERIMENTAL SECTION } & 10\end{array}$

$\begin{array}{lr}\text { General Considerations } & 10\end{array}$

Synthesis of $\left[\mathrm{Ru}\left(\mathrm{NH}_{3}\right)_{2} \underline{\left.\left(4,6-\mathrm{Me}_{2} \underline{\mathrm{DBT}}_{2}\right)\right]\left[\mathrm{PF}_{6}\right]_{2} \underline{2}_{2}(\mathbf{1}) .} \quad 10\right.$

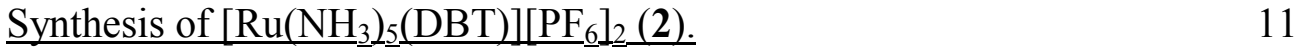

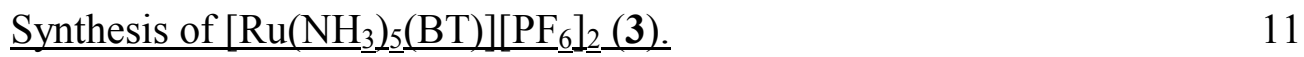

Synthesis of $\left[\mathrm{Ru}\left(\mathrm{NH}_{3} \underline{2}_{5} \underline{5}(\mathrm{~T})\right]\left[\mathrm{PF}_{6}\right]_{2} \underline{2}_{2}(4) . \quad 11\right.$

$\begin{array}{lr}\text { Extraction of DBT from Simulated Petroleum Fuel. } & 12\end{array}$

$\begin{array}{ll}\text { RESULTS AND DISCUSSION } & 13\end{array}$

$\underline{\text { Syntheses and Structures of }\left[\mathrm{Ru}\left(\mathrm{NH}_{3}\right)_{2} \text { (Thiophenes) }\right]\left[\mathrm{PF}_{6}\right]_{2} .} 13$ 
Oxidation of $\left[\mathrm{Ru}\left(\mathrm{NH}_{3}\right)_{2}\right.$ (Thiophenes) $)\left[\mathrm{PF}_{6}\right]_{2}$.

Extraction of DBT From Simulated Fuel by $\left[\mathrm{Ru}\left(\mathrm{NH}_{3}\right)_{2}\left(\mathrm{H}_{2} \underline{\mathrm{O}}\right)\right]\left[\mathrm{PF}_{6}\right]_{2}=\quad 18$

$\begin{array}{ll}\text { CONCLUSIONS } & 22\end{array}$

REFERENCES 
Page

Figure 1. Structures of thiophenes.

7

Scheme 1. Reactions of thiophene, benzothiophene, dibenzothiophene

and 4,6-dimethyldibenzothiophene with $\mathrm{Ru}\left(\mathrm{NH}_{3}\right)_{5}\left(\mathrm{H}_{2} \mathrm{O}\right)^{2+}$

14

Table 1. Comparison of the Affinities of Ligands for $\mathrm{Ru}\left(\mathrm{NH}_{3}\right)_{5}\left(\mathrm{H}_{2} \mathrm{O}\right)^{2+}$

and $\mathrm{Ru}\left(\mathrm{NH}_{3}\right)_{5}\left(\mathrm{H}_{2} \mathrm{O}\right)^{3+}$

Table 2. $\quad{ }^{1} \mathrm{H}$ and ${ }^{13} \mathrm{C}$ NMR Shifts (in ppm) of Thiophene, Benzothiophene,

Dibenzothiophene and 4,6-Dimethyldibenzothiophene.

Table 3. UV-Vis Spectra of $\mathrm{Ru}\left(\mathrm{NH}_{3}\right)_{5}\left(\mathrm{H}_{2} \mathrm{O}\right)^{2+}$ and Related Complexes.

Scheme 2. Cyclic oxidation of $\mathrm{Ru}^{\mathrm{II}}$ releasing DBT and reduction of $\mathrm{Ru}^{\mathrm{III}}$

by $\mathrm{H}_{2}$ on $\mathrm{Pd} / \mathrm{C}$.

Scheme 3. Reactor design for removal of DBT from low-sulfur feedstock.

Table 4. Extraction of DBT from Simulated Petroleum Fuel by

$\left[\mathrm{Ru}\left(\mathrm{NH}_{3}\right)_{5}\left(\mathrm{H}_{2} \mathrm{O}\right)\right]\left[\mathrm{PF}_{6}\right]_{2}$ in a 70:30 DMF: $\mathrm{H}_{2} \mathrm{O}$ Mixture. 
Figure 2. Equilibrium constants for the extraction of DBT with

$$
\mathrm{Ru}\left(\mathrm{NH}_{3}\right)_{5}\left(\mathrm{H}_{2} \mathrm{O}\right)^{2+} \text { in 70:30 DMF: } \mathrm{H}_{2} \mathrm{O}
$$




\section{EXECUTIVE SUMMARY}

The removal of sulfur from gasoline and diesel fuels is an important aspect of this nation's effort to reduce pollution of the atmosphere by sulfur oxides. The current EPAmandated $0.04 \%$ limit on sulfur in gasoline will be reduced to $0.0025 \%$ by 2006 . This reduction will require the development of new technologies. Such reductions in sulfur content must focus on the unreactive dibenzothiophene (DBT) derivatives that contain alkyl groups near the sulfur; these compounds constitute the bulk of the remaining sulfur compounds in hydrotreated petroleum feedstocks.

The present investigation focuses on $\mathrm{d}^{6}$ metal complexes that are capable of binding DBT and its derivatives. We have observed that $\mathrm{Ru}\left(\mathrm{NH}_{3}\right)_{5}\left(\mathrm{H}_{2} \mathrm{O}\right)^{2+}$ binds to DBT as well as its hindered 4,6-dimethyldibenzothiophene $\left(4,6-\mathrm{Me}_{2} \mathrm{DBT}\right)$ analog. It also reacts with thiophene and benzothiophene in acetone at $25^{\circ} \mathrm{C}$. By employing a solution of dimethylformamide and water (70:30) containing $\mathrm{Ru}\left(\mathrm{NH}_{3}\right)_{5}\left(\mathrm{H}_{2} \mathrm{O}\right)^{2+}$, we have extracted $50 \%$ of the DBT present in a simulated petroleum feedstock. We have also demonstrated oxidative release of DBT from the resulting $\mathrm{Ru}\left(\mathrm{NH}_{3}\right)_{5}(\mathrm{DBT})^{2+}$ complex. The oxidized ruthenium can be reduced back to $\mathrm{Ru}\left(\mathrm{NH}_{3}\right)_{5}\left(\mathrm{H}_{2} \mathrm{O}\right)^{2+}$ for further use. A reactor design has been proposed to make use of this DBT extraction process. 


\section{$\underline{\text { INTRODUCTION }}$}

Sulfur removal from gasoline and diesel fuels is an important aspect of this nation's effort to reduce pollution of the atmosphere by sulfur oxides. $\square_{\text {This reduction in }}$ sulfur has been largely accomplished by increasingly stringent restrictions on the sulfur content of these fuels. Currently, the sulfur content is limited to $0.04 \%$ by weight, but the EPA recently introduced a proposal aimed at reducing these levels gradually to $0.0025 \%$ by weight by $20062^{2}$ This ambitious agenda will require the development of new technologies in order to achieve such a reduction in sulfur content in a short period of time. Currently the extent of desulfurization and denitrogenation depends on the catalyst (Co-Mo/ $/ \mathrm{Al}_{2} \mathrm{O}_{3}, \mathrm{Ni}-\mathrm{Mo} / \mathrm{Al}_{2} \mathrm{O}_{3}$, and others) and the hydrotreating reaction conditions. ${ }_{\text {The }}$ most easily desulfurized components are the thiols (RSH) and thioethers (RSR). Recent improvements have yielded catalysts that are also capable of desulfurizing the thiophenes, benzothiophenes and dibenzothiophenes $(\mathrm{R}=\mathrm{H})$ (below). It is the hindered dibenzothiophenes $\left(\mathrm{R}_{2} \mathrm{DBT}\right)$ with alkyl groups in the 4- and 6- positions that are

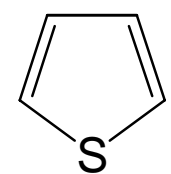

thiophene, $\mathrm{T}$

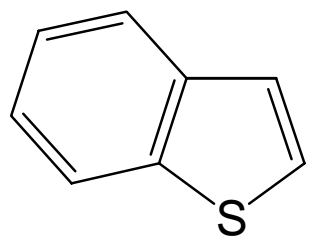

benzothiophene, BT

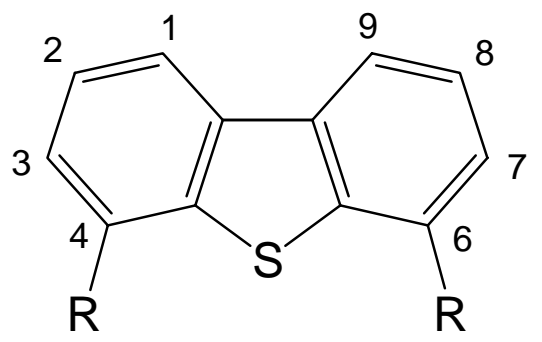

dibenzothiophene, $\mathrm{R}_{2} \mathrm{DBT}$ where $\mathrm{R}=\mathrm{H}$, Me, Et, etc.

Figure 1. Structures of thiophenes. 
the slowest to undergo hydrodesulfurization. Moreover, it is these hindered dibenzothiophenes that must be desulfurized in order to reach lower sulfur levels in gasolines. It is the steric congestion of the 4,6-groups near the sulfur atom that reduces the activity of dibenzothiophenes in the hydrotreating process. The reaction on a catalytic surface requires the sulfur atom of a dibenzothiophene molecule to interact with the surface. This is nearly impossible due to the methyl groups at the 4,6-positions. Even in coordination compounds only one example of a $\eta^{1}-\mathrm{S}$ bound 4,6dimethyldibenzothiophene has been reported. ${ }^{9}$ Substantial efforts to create catalysts that are able to promote deep hydrodesulfurization of petroleum feedstocks, which requires the desulfurization of these hindered dibenzothiophenes at reasonable cost, have not been successful.

Considering the lack of success in developing more effective catalysts, we have developed a completely different approach to the removal of hindered dibenzothiophenes $\left(\mathrm{R}_{2} \mathrm{DBT}\right)$ from petroleum. This approach, elegant in its simplicity, involves the use of $\mathrm{Ru}\left(\mathrm{NH}_{3}\right)_{5}\left(\mathrm{H}_{2} \mathrm{O}\right)^{2+}$ to selectively bind and extract $4,6-\mathrm{R}_{2} \mathrm{DBT}$ molecules from petroleum feedstocks. Then, the 4,6- $\mathrm{R}_{2} \mathrm{DBT}$ molecules can be removed from the $\mathrm{Ru}\left(\mathrm{NH}_{3}\right)_{5}(4,6-$ $\mathrm{R}_{2} \mathrm{DBT}^{2+}$ by air oxidation. Reduction of the resulting $\mathrm{Ru}^{3+}$ complex with $\mathrm{H}_{2}$ gives back the extracting $\mathrm{Ru}\left(\mathrm{NH}_{3}\right)_{5}\left(\mathrm{H}_{2} \mathrm{O}\right)^{2+}$ complex. 


\section{EXPERIMENTAL}

General Considerations. All reactions were carried out under an atmosphere of dry argon using standard Schlenk techniques. Diethyl ether $\left(\mathrm{Et}_{2} \mathrm{O}\right)$ was purified on alumina using a Solv-Tech solvent purification system, as described by Grubbs and co-workers. All other chemicals were used without further purification as purchased from Aldrich. Filtrations were performed with celite on filter paper.

NMR spectra were obtained on a modified $400 \mathrm{MHz}$ Varian VXR-400 spectrometer using $\mathrm{CD}_{3} \mathrm{COCD}_{3}$ as internal lock and reference. Elemental analyses were performed on a Perkin-Elmer 2400 series II CHNS/O analyzer. UV-Vis spectra were obtained on a Hewlett Packard 8452A Diode Array Spectrophotometer with a deuterium lamp, using quartz cuvettes.

Synthesis of $\left[\mathbf{R u}\left(\mathbf{N H}_{3}\right)_{5}\left(4,6-\mathbf{M e}_{2} \mathbf{D B T}\right)\right]\left[\mathbf{P F}_{\mathbf{6}}\right]_{\mathbf{2}}(\mathbf{1})$. To a $50 \mathrm{~mL}$ flask containing $15 \mathrm{~mL}$ of acetone or dimethylformamide (DMF), freshly prepared $\left[\mathrm{Ru}\left(\mathrm{NH}_{3}\right)_{5}\left(\mathrm{H}_{2} \mathrm{O}\right)\right]\left[\mathrm{PF}_{6}\right]_{2}(50 \mathrm{mg}$, $0.102 \mathrm{mmol})^{6}$, 4,6-dimethyldibenzothiophene (4,6-Me 2 DBT) $(29 \mathrm{mg}, 0.136 \mathrm{mmol})$, and palladium (10 wt. $\%$ on activated carbon) $(10 \mathrm{mg})$ were added. The solution was cycled through three freeze/pump/thaw sequences to remove air from the system. The flask was warmed to room temperature and $\mathrm{H}_{2}(\mathrm{~g})$ was bubbled through the solution for $15 \mathrm{~min}$. The resulting yellow solution was allowed to stand under $\mathrm{H}_{2}$ for $45 \mathrm{~min}$. The product was precipitated with $35 \mathrm{~mL}$ of $\mathrm{Et}_{2} \mathrm{O}$, and the solution was filtered to remove excess 4,6$\mathrm{Me}_{2} \mathrm{DBT}$. The product was dissolved by adding $10 \mathrm{~mL}$ of acetone, which had been cycled through three freeze/pump/thaw sequences and warmed to room temperature. Then, $\mathrm{H}_{2}$ was bubbled through the solution for $5 \mathrm{~min}$. The solution was then filtered (to remove 
$\mathrm{Pd} / \mathrm{C}$ ) into another flask containing $35 \mathrm{~mL}$ of $\mathrm{Et}_{2} \mathrm{O}$, which gave the product as a

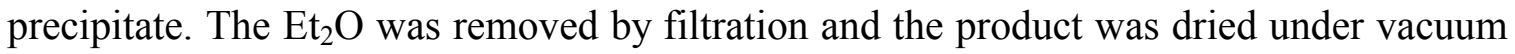
for 15 min to give an $86 \%$ yield. ${ }^{1} \mathrm{H}$ NMR $\left(400 \mathrm{MHz}, \mathrm{CD}_{3} \mathrm{COCD}_{3}\right): \delta 8.37\left(\mathrm{~d}, \mathrm{~J}_{\mathrm{H}-\mathrm{H}}=12\right.$ Hz, 2 H, DBT- $H$ ), 8.05 (d, J $\left.\mathrm{J}_{\mathrm{H}-\mathrm{H}}=12 \mathrm{~Hz}, 2 \mathrm{H}, \mathrm{DBT}-H\right), 7.68$ (t, J $\mathrm{J}_{\mathrm{H}-\mathrm{H}}=12 \mathrm{~Hz}, 2 \mathrm{H}$, DBTH), 2.62 (s, 6H, DBT-CH $H_{3}$ ), 2.70 (s, br, $12 \mathrm{H}, \mathrm{NH}_{3}$ ), 2.52 (s, br, $3 \mathrm{H}, \mathrm{NH}_{3}$ ) ppm. ${ }^{13} \mathrm{C} \mathrm{NMR}$ (400 MHz, $\left.\mathrm{CD}_{3} \mathrm{COCD}_{3}\right): \delta$ (quaternary C's unobservable) $127.50,125.32,119.82,15.01$ ppm.

Synthesis of $\left[\mathbf{R u}\left(\mathrm{NH}_{3}\right)_{5}(\mathrm{DBT})\right]\left[\mathrm{PF}_{6}\right]_{2}(\mathbf{2})$. The same procedure as (1) was followed with the exception that DBT ( $25 \mathrm{mg}, 0.136 \mathrm{mmol}$ ) was used in place of 4,6-Me 2 DBT. ${ }^{1} \mathrm{H}$ NMR $\left(400 \mathrm{MHz}, \mathrm{CD}_{3} \mathrm{COCD}_{3}\right): \delta 8.38\left(\mathrm{~d}, 2 \mathrm{H}, \mathrm{J}_{\mathrm{H}-\mathrm{H}}=12 \mathrm{~Hz}, \mathrm{DBT}-H\right), 8.05\left(\mathrm{~d}, 2 \mathrm{H}, \mathrm{J}_{\mathrm{H}-\mathrm{H}}=12 \mathrm{~Hz}\right.$, DBT-H), $7.68\left(\mathrm{t}, 2 \mathrm{H}, \mathrm{J}_{\mathrm{H}-\mathrm{H}}=12 \mathrm{~Hz}, \mathrm{DBT}-H\right), 7.54\left(\mathrm{t}, 2 \mathrm{H}, \mathrm{J}_{\mathrm{H}-\mathrm{H}}=12 \mathrm{~Hz}, \mathrm{DBT}-H\right), 2.69(\mathrm{~s}$, br, $\left.12 \mathrm{H}, \mathrm{NH}_{3}\right), 2.53$ (s, br, $\left.3 \mathrm{H}, \mathrm{NH}_{3}\right)$ ppm. ${ }^{13} \mathrm{C} \mathrm{NMR}\left(400 \mathrm{MHz}, \mathrm{CD}_{3} \mathrm{COCD}_{3}\right): \delta 143.12$, $138.62,127.95,125.10,123.11,121.95 \mathrm{ppm}$.

Synthesis of $\left[\mathbf{R u}\left(\mathrm{NH}_{3}\right)_{5}(\mathbf{B T})\right]\left[\mathrm{PF}_{6}\right]_{2}(3)$. The same procedure as (1) was followed with the exception that BT (15 mg, $0.125 \mathrm{mmol})$ was used in place of 4,6-Me 2 DBT. ${ }^{1} \mathrm{H}$ NMR (400 MHz, $\left.\mathrm{CD}_{3} \mathrm{COCD}_{3}\right): \delta 8.1-7.4(\mathrm{~m}, 4 \mathrm{H}, \mathrm{BT}-H), 6.5\left(\mathrm{~d}, 1 \mathrm{H}, \mathrm{J}_{\mathrm{H}-\mathrm{H}}=8 \mathrm{~Hz}, \mathrm{BT}-H\right), 6.0(\mathrm{~d}$, $\left.1 \mathrm{H}, \mathrm{J}_{\mathrm{H}-\mathrm{H}}=8 \mathrm{~Hz}, \mathrm{BT}-H\right), 2.72\left(\mathrm{~s}, \mathrm{br}, 12 \mathrm{H}, \mathrm{NH}_{3}\right), 2.56\left(\mathrm{~s}, \mathrm{br}, 3 \mathrm{H}, \mathrm{N} H_{3}\right) \mathrm{ppm} .{ }^{13} \mathrm{C} \mathrm{NMR}$ $\left(400 \mathrm{MHz}, \mathrm{CD}_{3} \mathrm{COCD}_{3}\right): \delta 142.54,139.52,128.12,127.72,125.98,124.68,123.85$, $122.56 \mathrm{ppm}$. 
Synthesis of $\left[\mathbf{R u}\left(\mathbf{N H}_{3}\right)_{5}(\mathbf{T})\right]\left[\mathbf{P F}_{\mathbf{6}}\right]_{2}(\mathbf{4})$. The same procedure as (1) was followed with the exception that $\mathrm{T}(15 \mu \mathrm{L}, 0.188 \mathrm{mmol})$ was used in place of $4,6-\mathrm{Me}_{2} \mathrm{DBT} .{ }^{1} \mathrm{H}$ NMR (400 $\left.\mathrm{MHz}, \mathrm{CD}_{3} \mathrm{COCD}_{3}\right): \delta 7.49\left(\mathrm{~m}, 2 \mathrm{H}, \mathrm{J}_{\mathrm{H}-\mathrm{H}}=8 \mathrm{~Hz}, \mathrm{~T}-H\right), 7.13\left(\mathrm{~m}, 2 \mathrm{H}, \mathrm{J}_{\mathrm{H}-\mathrm{H}}=8 \mathrm{~Hz}, \mathrm{~T}-H\right), 2.71$ (s, br, $\left.12 \mathrm{H}, \mathrm{N} H_{3}\right), 2.48\left(\mathrm{~s}, \mathrm{br}, 3 \mathrm{H}, \mathrm{NH} H_{3}\right) \mathrm{ppm} .{ }^{13} \mathrm{C} \mathrm{NMR}\left(400 \mathrm{MHz}, \mathrm{CD}_{3} \mathrm{COCD}_{3}\right): \delta$ $127.08,125.34 \mathrm{ppm}$.

Extraction of DBT from Simulated Petroleum Fuel. A mixture of toluene $(45 \%$ by volume) and hexanes (55\% by volume) was made to simulate the composition of a hydrotreated petroleum feedstock. ${ }^{4 a}$ Into $10 \mathrm{~mL}$ of this liquid, DBT (17.6 mg, 0.095 mmol, $0.04 \%$ by weight) and triphenylmethane $(15 \mathrm{mg}, 0.061 \mathrm{mmol})$ (internal standard) were dissolved. The solution was cycled through 3 freeze/pump/thaw cycles and warmed to room temperature. Into a separate flask, $7 \mathrm{~mL}$ of DMF, $3 \mathrm{~mL}$ of $\mathrm{H}_{2} \mathrm{O}, \mathrm{Pd}(10 \mathrm{wt} . \%$ on activated carbon) (10 mg), and either a five-fold or ten-fold molar excess of $\left[\mathrm{Ru}\left(\mathrm{NH}_{3}\right)_{5}\left(\mathrm{H}_{2} \mathrm{O}\right)\right]\left[\mathrm{PF}_{6}\right]_{2}$ was added (five fold $=234.78 \mathrm{mg}, 0.477 \mathrm{mmol}$; ten fold $=469.54$ $\mathrm{mg}, 0.954 \mathrm{mmol})$. The mixture was cycled through 3 freeze/pump/thaw cycles, warmed to room temperature, and $\mathrm{H}_{2}(\mathrm{~g})$ was bubbled through the solution for $10 \mathrm{~min}$. A $0.4 \mathrm{~mL}$ aliquot of the DBT containing solution was taken for NMR analysis; the remainder of the DBT solution was added to the $\left[\mathrm{Ru}\left(\mathrm{NH}_{3}\right)_{5}\left(\mathrm{H}_{2} \mathrm{O}\right)\right]\left[\mathrm{PF}_{6}\right]_{2}$ mixture under argon. The mixture was sonicated and $0.4 \mathrm{~mL}$ aliquots of the organic phase were removed at $0.25,0.5,0.75$, 1.0, 2.0, and $4.0 \mathrm{hrs}$. The organic solvents were removed by evaporation and the ratio of DBT $(\delta 8.33 \mathrm{ppm})$ to triphenylmethane $(\delta 5.63 \mathrm{ppm})$ was determined by integration of the ${ }^{1} \mathrm{H}$ NMR bands to establish the amount of DBT that was removed from the simulated fuel mixture. 


\section{$\underline{\text { RESULTS AND DISCUSSION }}$}

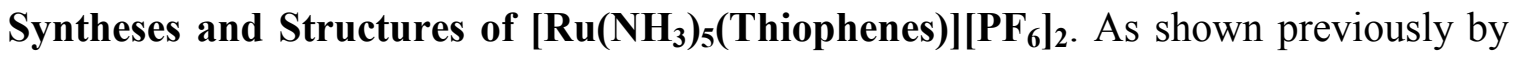
Taube and co-workers, $\mathrm{Z}_{\mathrm{Ru}}\left(\mathrm{NH}_{3}\right)_{5}\left(\mathrm{H}_{2} \mathrm{O}\right)^{2+}$ coordinates thiophene to form the unstable $\mathrm{Ru}\left(\mathrm{NH}_{3}\right)_{5}(\mathrm{~T})^{2+}$ complex. We have found that BT, DBT, and most importantly 4,6$\mathrm{Me}_{2} \mathrm{DBT}$ react with $\mathrm{Ru}\left(\mathrm{NH}_{3}\right)_{5}\left(\mathrm{H}_{2} \mathrm{O}\right)^{2+}$ under mild conditions in acetone to give the corresponding $\mathrm{Ru}\left(\mathrm{NH}_{3}\right)_{5}(\text { Thiophenes })^{2+}$ complexes (Scheme 1).

As shown in Table 2, the chemical shifts of the ${ }^{1} \mathrm{H}$ and ${ }^{13} \mathrm{C}$ NMR bands of the thiophene ligands are noticeably different in the $\mathrm{Ru}\left(\mathrm{NH}_{3}\right)_{5}(\text { Thiophenes })^{2+}$ complexes than the free thiophenes. These NMR data clearly show that the thiophene ligands are $\eta^{1}-\mathrm{S}-$ coordinated in these complexes. ${ }^{\mathrm{Z}}$ The reactions of the thiophenes with $\mathrm{Ru}\left(\mathrm{NH}_{3}\right)_{5}\left(\mathrm{H}_{2} \mathrm{O}\right)^{2+}$ are complete within $35 \mathrm{~min}$, but the products are very air sensitive. For this reason, we add $10 \mathrm{mg}$ of $\mathrm{Pd} / \mathrm{C}\left(10 \%\right.$ by weight) and bubble $\mathrm{H}_{2}$ for $15 \mathrm{~min}$ through the solution in order to maintain the $\mathrm{Ru}\left(\mathrm{NH}_{3}\right)_{5}(\text { Thiophenes })^{2+}$ products in the reduced $\mathrm{Ru}^{2+}$ form. Additional $\mathrm{H}_{2}$ is added periodically when the solution begins to darken indicating the formation of the red $\mathrm{Ru}\left(\mathrm{NH}_{3}\right)_{5}\left(\mathrm{H}_{2} \mathrm{O}\right)^{3+}$ complex.

While many DBT metal complexes are known ${ }^{1}, \mathrm{Ru}\left(\mathrm{NH}_{3}\right)_{5}\left(4,6-\mathrm{Me}_{2} \mathrm{DBT}\right)^{2+}$ is among the first $\eta^{1}$-S coordinated 4,6-dimethyldibenzothiophene coordination complexes; due to its air sensitivity, satisfactory elemental analyses for this compound were not obtained. Jones and coworkers ${ }^{9}$ were the first to observe a 4,6- $\mathrm{Me}_{2} \mathrm{DBT}$ complex, $\mathrm{Cp}^{*} \mathrm{Rh}\left(\mathrm{PMe}_{3}\right)(4,6-\mathrm{DMDBT})$, by ${ }^{1} \mathrm{H}$ NMR spectroscopy, but the compound was too unstable to isolate. Two other examples of 4,6- $\mathrm{Me}_{2} \mathrm{DBT}$ complexes are known, cis 

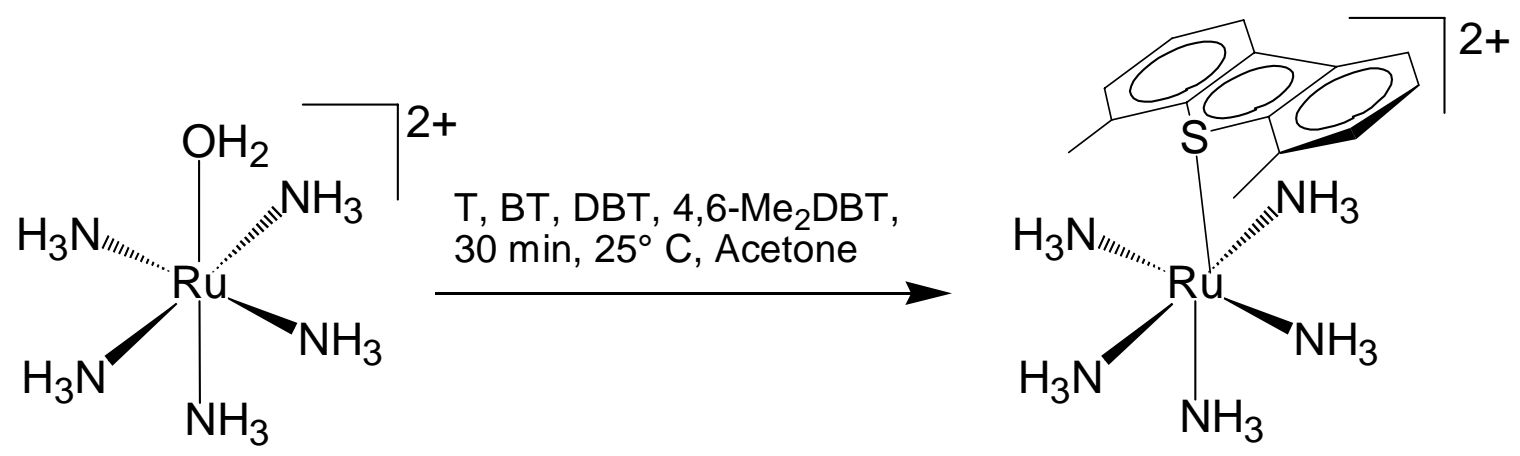

Scheme 1. Reactions of thiophene, benzothiophene, dibenzothiophene and 4,6dimethyldibenzothiophene with $\mathrm{Ru}\left(\mathrm{NH}_{3}\right)_{5}\left(\mathrm{H}_{2} \mathrm{O}\right)^{2+}$.

Table 1. Comparison of the Affinities of Ligands for $\mathrm{Ru}\left(\mathrm{NH}_{3}\right)_{5}\left(\mathrm{H}_{2} \mathrm{O}\right)^{2+}$ and $\mathrm{Ru}\left(\mathrm{NH}_{3}\right)_{5}\left(\mathrm{H}_{2} \mathrm{O}\right)^{3+}$. Partially Adapted from Taube and Kuehn. ${ }^{7}$

\begin{tabular}{|c|c|c|c|c|}
\hline & $\mathrm{Ru}\left(\mathrm{NH}_{3}\right)_{5}\left(\mathrm{H}_{2} \mathrm{O}\right)^{2+}$ & $\mathrm{Ru}\left(\mathrm{NH}_{3}\right)_{5}\left(\mathrm{H}_{2} \mathrm{O}\right)^{3+}$ & Ratio & Ref \\
\hline Pyridine & $2.4 \times 10^{7}$ & $6 \times 10^{3}$ & $4 \times 10^{3}$ & 10 \\
\hline Imidazole & $2.8 \times 10^{6}$ & $1.9 \times 10^{6}$ & 1.5 & 11 \\
\hline $\mathrm{HS}^{-}$ & $1.5 \times 10^{6}$ & $2.4 \times 10^{13}$ & $6 \times 10^{-8}$ & \\
\hline$\left(\mathrm{CH}_{3}\right)_{2} \mathrm{~S}$ & $>10^{5}$ & $>1.6 \times 10^{-2}$ & $\sim 6 \times 10^{6}$ & \\
\hline $\mathrm{NH}_{3}$ & $3.5 \times 10^{4}$ & $1.6 \times 10^{5}$ & $2 \times 10^{-1}$ & \\
\hline $\mathrm{N}_{2}$ & $3.3 \times 10^{4}$ & $4 \times 10^{-13}$ & $8 \times 10^{16}$ & 12 \\
\hline $2,8-\mathrm{Me}_{2} \mathrm{DBT}$ & $3.6 \times 10^{3}$ (estimate) & - & - & 16 \\
\hline $\mathrm{H}_{2} \mathrm{~S}$ & $1.5 \times 10^{3}$ & $2.4 \times 10^{-4}$ & $6 \times 10^{6}$ & \\
\hline DBT & $7.4 \times 10^{2}$ (estimate) & - & - & 16 \\
\hline $\mathrm{HO}^{-}$ & $6 \times 10^{2}$ & $6 \times 10^{11}$ & $1 \times 10^{-9}$ & \\
\hline Thiophene & $\sim 10$ & $\sim 2.5 \times 10^{-8}$ & $4 \times 10^{8}$ & \\
\hline $\mathrm{H}_{2} \mathrm{O}$ & 1 & 1 & 1 & \\
\hline $\mathrm{Cl}^{-}$ & 0.4 & $1.1 \times 10^{2}$ & $4 \times 10^{-1}$ & 13 \\
\hline
\end{tabular}


Table 2. ${ }^{1} \mathrm{H}$ and ${ }^{13} \mathrm{C}$ NMR Shifts (in ppm) of Thiophene (T), Benzothiophene (BT), Dibenzothiophene (DBT) and 4,6-Dimethyldibenzothiophene (4,6-Me 2 DBT) Unbound and Bound in $\mathrm{Ru}\left(\mathrm{NH}_{3}\right)_{5}\left(\mathrm{Thiophene}^{2+}\right.$.

\begin{tabular}{lllll}
\hline Ligand & $\begin{array}{l}{ }^{1} \mathrm{H} \text { NMR } \\
\text { Unbound }\end{array}$ & $\begin{array}{l}{ }^{1} \mathrm{H} \text { NMR } \\
\text { Bound }\end{array}$ & $\begin{array}{l}{ }^{13} \mathrm{C} \text { NMR } \\
\text { Unbound }\end{array}$ & $\begin{array}{l}{ }^{13} \mathrm{C} \text { NMR } \\
\text { Bound }\end{array}$ \\
\hline $\mathrm{T}$ & $7.47,7.15$ & $7.49,7.13$ & $127.12,125.39$ & $127.08,125.34$ \\
$\mathrm{BT}$ & $7.97,7.88$, & $8.1-7.4(\mathrm{~m})$, & $140.08,139.91$, & $142.54,139.52$, \\
& $7.64,7.43$, & $6.5,6.0$ & $126.81,124.46$, & $128.12,127.72$, \\
& 7.36 & & $124.39,124.16$, & $125.98,124.68$, \\
& & $123.82,122.62$ & $123.85,122.56$ \\
& & & \\
$\mathrm{DBT}$ & $8.33,7.98$, & $8.38,8.05$, & $139.38,136.82$, & $143.12,138.62$, \\
& $7.51(\mathrm{~m})$ & $7.68,7.54$ & $127.23,124.82$, & $127.95,125.10$, \\
& & & $123.05,122.01$ & $123.11,121.95$ \\
& & & \\
$4,6-\mathrm{Me}_{2} \mathrm{DBT}$ & $8.12,7.43$, & $8.37,8.05$, & $139.12,136.28$, & $127.50,125.32$, \\
& $7.35,2.59$ & $7.68,2.62$ & $127.30,125.31$, & $119.82,15.01$ \\
& & & $119.71,19.82$ & \\
\hline
\end{tabular}

$-\left[\left(\mathrm{PEt}_{3}\right)_{2} \mathrm{Pt}\left(4,6-\mathrm{Me}_{2} \mathrm{DBT}\right)\right]^{14}$ and $\left[(\text { dippe }) \mathrm{Pt}\left(4,6-\mathrm{Me}_{2} \mathrm{DBT}\right)\right]^{[5}$, neither are $\eta^{1}-\mathrm{S}$-coordinated but the result of $\mathrm{Pt}$ insertion into a $\mathrm{C}-\mathrm{S}$ bond.

The affinity of $\mathrm{Ru}\left(\mathrm{NH}_{3}\right)_{5}\left(\mathrm{H}_{2} \mathrm{O}\right)^{2+}$ for different ligands is summarized in Table 1. In hydrotreated petroleum feedstocks $\mathrm{DBT}$ and $\mathrm{R}_{2} \mathrm{DBT}$ are the main components that must be removed. Table 1 shows that thiophene binds favorably to $\mathrm{Ru}\left(\mathrm{NH}_{3}\right)_{5}\left(\mathrm{H}_{2} \mathrm{O}\right)^{2+}$. However, DBT binds even more strongly based on equilibrium studies of thiophene displacement from other $\mathrm{Ru}$ complexes, $\left(\eta^{5}-\mathrm{C}_{5} \mathrm{H}_{5}\right) \mathrm{Ru}(\mathrm{CO})\left(\mathrm{PPh}_{3}\right)(\text { Thiophene })^{+}{ }^{16}$ When comparing the binding strengths of thiophenes, DBT and 2,8-dimethydibenzothiophene bind 74.1 and 358 times more strongly than thiophene. ${ }^{17}$ As shown in Table 1, 2,8$\mathrm{Me}_{2} \mathrm{DBT}$ with methyl groups in the non-hindering 2,8-positions binds five times more strongly to $\mathrm{Ru}\left(\mathrm{NH}_{3}\right)_{5}\left(\mathrm{H}_{2} \mathrm{O}\right)^{2+}$ than DBT due to the enhanced $\sigma$-donating ability of the 
methyl groups. This result suggests that the placement of the methyl groups in the 4,6positions in $4,6-\mathrm{Me}_{2} \mathrm{DBT}$ sterically inhibits its binding in metal complexes.

By slightly changing the $\mathrm{NH}_{3}$ ligands in $\mathrm{Ru}\left(\mathrm{NH}_{3}\right)_{5}\left(\mathrm{H}_{2} \mathrm{O}\right)^{2+}$, the reactivity of the system is changed greatly. We have found that trans- $\left[\mathrm{Ru}(\text { pyridine })\left(\mathrm{NH}_{3}\right)_{4}\left(\mathrm{H}_{2} \mathrm{O}\right)^{2+}\right]^{18}$ and mer- $\left[\mathrm{Ru}(\text { bipy })\left(\mathrm{NH}_{3}\right)_{3}\left(\mathrm{H}_{2} \mathrm{O}\right)^{2+}\right]^{19}$ both do not react with thiophene or dibenzothiophene, despite the fact that molecular models show no obvious steric interactions. This reactivity is counter-intuitive, since removal of electron density from the $\mathrm{Ru}$ by the pyridine ligand should enhance the ability of $\mathrm{Ru}$ to bind $\sigma$-donating thiophenes.

Table 3. UV-Vis Spectra of $\mathrm{Ru}\left(\mathrm{NH}_{3}\right)_{5}\left(\mathrm{H}_{2} \mathrm{O}\right)^{2+}$ and Related Complexes in Acetone Solvent.

\section{Compound}

DBT

$\mathrm{Ru}\left(\mathrm{NH}_{3}\right)_{5}\left(\mathrm{H}_{2} \mathrm{O}\right)^{2+}$

$\mathrm{Ru}\left(\mathrm{NH}_{3}\right)_{5}(\mathrm{DBT})^{2+}$

$\mathrm{Ru}\left(\mathrm{NH}_{3}\right)_{5}\left(\mathrm{H}_{2} \mathrm{O}\right)^{2+}$ oxidized $25 \mathrm{~min}$

to $\mathrm{Ru}\left(\mathrm{NH}_{3}\right)_{5}\left(\mathrm{H}_{2} \mathrm{O}\right)^{3+}$

$\mathrm{Ru}\left(\mathrm{NH}_{3}\right)_{5}\left(\mathrm{H}_{2} \mathrm{O}\right)^{3+}$ reduced to

$\mathrm{Ru}\left(\mathrm{NH}_{3}\right)_{5}\left(\mathrm{H}_{2} \mathrm{O}\right)^{2+}$

\section{$\lambda_{\max }$}

$330 \mathrm{~nm}$

358 (br), 420 (sh) nm

328,358 (br), 420 (sh) nm

380 (br), 535 (br) nm

348 (br), 420 (sh) nm

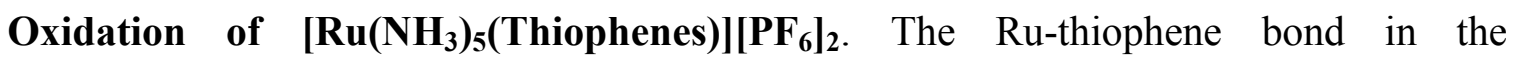
$\mathrm{Ru}\left(\mathrm{NH}_{3}\right)_{5}(\text { Thiophene })^{2+}$ complexes appears to be quite weak. This weak interaction is reflected in the nearly identical UV-Vis spectra (Table 3) of $\mathrm{Ru}\left(\mathrm{NH}_{3}\right)_{5}\left(\mathrm{H}_{2} \mathrm{O}\right)^{2+}$ and $\mathrm{Ru}\left(\mathrm{NH}_{3}\right)_{5}(\mathrm{DBT})^{2+}$. 
The $\mathrm{Ru}\left(\mathrm{NH}_{3}\right)_{5}(\text { Thiophenes })^{2+}$ complexes are very air sensitive with respect to oxidation. When an acetone solution of $\mathrm{Ru}\left(\mathrm{NH}_{3}\right)_{5}$ (Thiophenes $)^{2+}$ is exposed to air, the $\mathrm{Ru}\left(\mathrm{NH}_{3}\right)_{5}(\text { Thiophenes })^{2+} \quad$ complexes are oxidized within 20 minutes to $\mathrm{Ru}\left(\mathrm{NH}_{3}\right)_{5}(\text { solvent })^{3+}$. The fact that $\mathrm{Ru}^{3+}$ has essentially no affinity for thiophenes means that upon oxidation, any thiophene coordinated to $\mathrm{Ru}^{3+}$ is released into solution forming $\mathrm{Ru}\left(\mathrm{NH}_{3}\right)_{5}(\text { solvent })^{3+}$. This means that if $\mathrm{Ru}\left(\mathrm{NH}_{3}\right)_{5}\left(\mathrm{H}_{2} \mathrm{O}\right)^{2+}$ is used to extract thiophenes from petroleum fuels by forming $\mathrm{Ru}\left(\mathrm{NH}_{3}\right)_{5}$ (Thiophenes) $)^{2+}$, the thiophene may be released from the $\mathrm{Ru}^{2+}$ complex by air-oxidation to $\mathrm{Ru}^{3+}$.

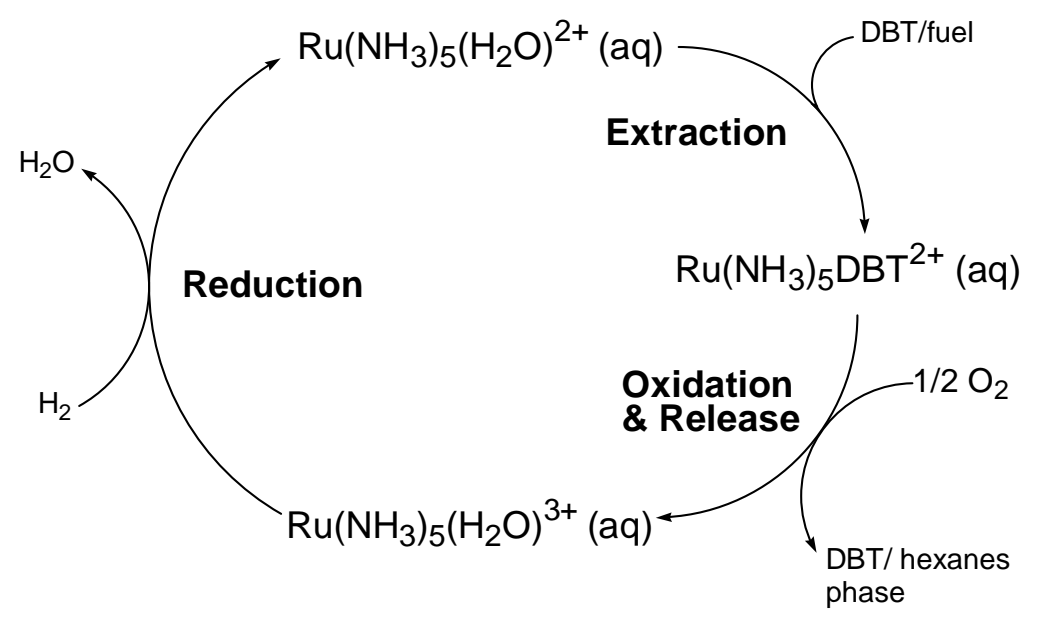

Scheme 2. Cyclic oxidation of $\mathrm{Ru}^{\mathrm{II}}$ releasing $\mathrm{DBT}$ and reduction of $\mathrm{Ru}$ III by $\mathrm{H}_{2}$ on $\mathrm{Pd} / \mathrm{C}$.

Extraction of DBT from Simulated Fuel by $\left[\mathrm{Ru}\left(\mathrm{NH}_{3}\right)_{5}\left(\mathrm{H}_{2} \mathrm{O}\right)\right]\left[\mathrm{PF}_{6}\right]_{2}$. The traditional method of removing sulfur from feedstocks by hydrotreating over $\mathrm{Co}-\mathrm{Mo} / \mathrm{Al}_{2} \mathrm{O}_{3}$ and $\mathrm{Ni}$ $\mathrm{Mo} / \mathrm{Al}_{2} \mathrm{O}_{3}$ catalysts is a mature field and unlikely to achieve the necessary low-sulfur fuels required by the EPA. ${ }^{2}$ A new approach is needed to reach these very low levels of sulfur. We believe that such an approach must meet the following criteria: 1) it must be able to reduce or remove DBT and 4,6- $\mathrm{Me}_{2} \mathrm{DBT}, 2$ ) it must be economically viable, 3 ) 
and it must be heterogeneous in nature. These criteria are addressed by our process in the following ways: 1) we have shown that DBT and 4,6-Me $2 \mathrm{DBT}$ coordinate to $\mathrm{Ru}\left(\mathrm{NH}_{3}\right)_{5}\left(\mathrm{H}_{2} \mathrm{O}\right)^{2+}$, 2) the oxidation process is economically viable because $\mathrm{Ru}\left(\mathrm{NH}_{3}\right)_{5}\left(\mathrm{H}_{2} \mathrm{O}\right)^{2+}$ is recycled after each step, and only $\mathrm{H}_{2}$ and $\mathrm{O}_{2}$ are consumed, and 3) this process is heterogeneous, because the DBT and the 4,6- $\mathrm{Me}_{2} \mathrm{DBT}$ molecules are extracted from the hydrocarbon fuel phase into an aqueous phase.

Here, we offer a process (Scheme 2) based on the above studies of $\mathrm{Ru}\left(\mathrm{NH}_{3}\right)_{5}\left(\mathrm{H}_{2} \mathrm{O}\right)^{2+}$ extraction of DBT from hydrotreated petroleum feedstocks. The process uses two phases, one hydrophilic (70\% DMF, 30\% $\mathrm{H}_{2} \mathrm{O}$ ) and the other hydrophobic (the fuel feedstock that has already been hydrotreated). In chamber $\mathbf{A}$ (Scheme 2), DBT is extracted from the feedstock phase into the hydrophilic phase that contains $\mathrm{Ru}\left(\mathrm{NH}_{3}\right)_{5}\left(\mathrm{H}_{2} \mathrm{O}\right)^{2+}, \mathrm{Pd} / \mathrm{C}$, and bubbling $\mathrm{H}_{2}$. It is the complexation of the DBT as $\mathrm{Ru}\left(\mathrm{NH}_{3}\right)_{5}(\mathrm{DBT})^{2+}$ that causes the DBT to move into the $\mathrm{DMF} / \mathrm{H}_{2} \mathrm{O}$ phase. This $\mathrm{DMF} / \mathrm{H}_{2} \mathrm{O}$ phase containing $\mathrm{Ru}\left(\mathrm{NH}_{3}\right)_{5}(\mathrm{DBT})^{2+}$ is drained into a second chamber $\mathbf{B}$ where the $\mathrm{Ru}\left(\mathrm{NH}_{3}\right)_{5}(\mathrm{DBT})^{2+}$ is oxidized with $\mathrm{O}_{2}$ (air) to give $\mathrm{Ru}\left(\mathrm{NH}_{3}\right)_{5}\left(\mathrm{H}_{2} \mathrm{O}\right)^{3+}$ and free DBT. The DBT, preferring a hydrophobic solvent, transfers into a hydrocarbon phase (which could be incinerated as waste). Finally the $\mathrm{Ru}\left(\mathrm{NH}_{3}\right)_{5}\left(\mathrm{H}_{2} \mathrm{O}\right)^{3+}$ is cycled back to the main chamber $\mathbf{A}$ where it is reduced by $\mathrm{H}_{2} / \mathrm{Pd} / \mathrm{C}$ back to the active $\mathrm{Ru}\left(\mathrm{NH}_{3}\right)_{5}\left(\mathrm{H}_{2} \mathrm{O}\right)^{2+}$, which can extract more DBT from the fuel.

In order to demonstrate the feasibility of the DBT extraction in chamber A, we performed the following series of extraction studies. First a simulated feedstock of $45 \%$ toluene and 55\% hexane containing $0.04 \%$ DBT was extracted with $70 \%$ DMF and 30\% 


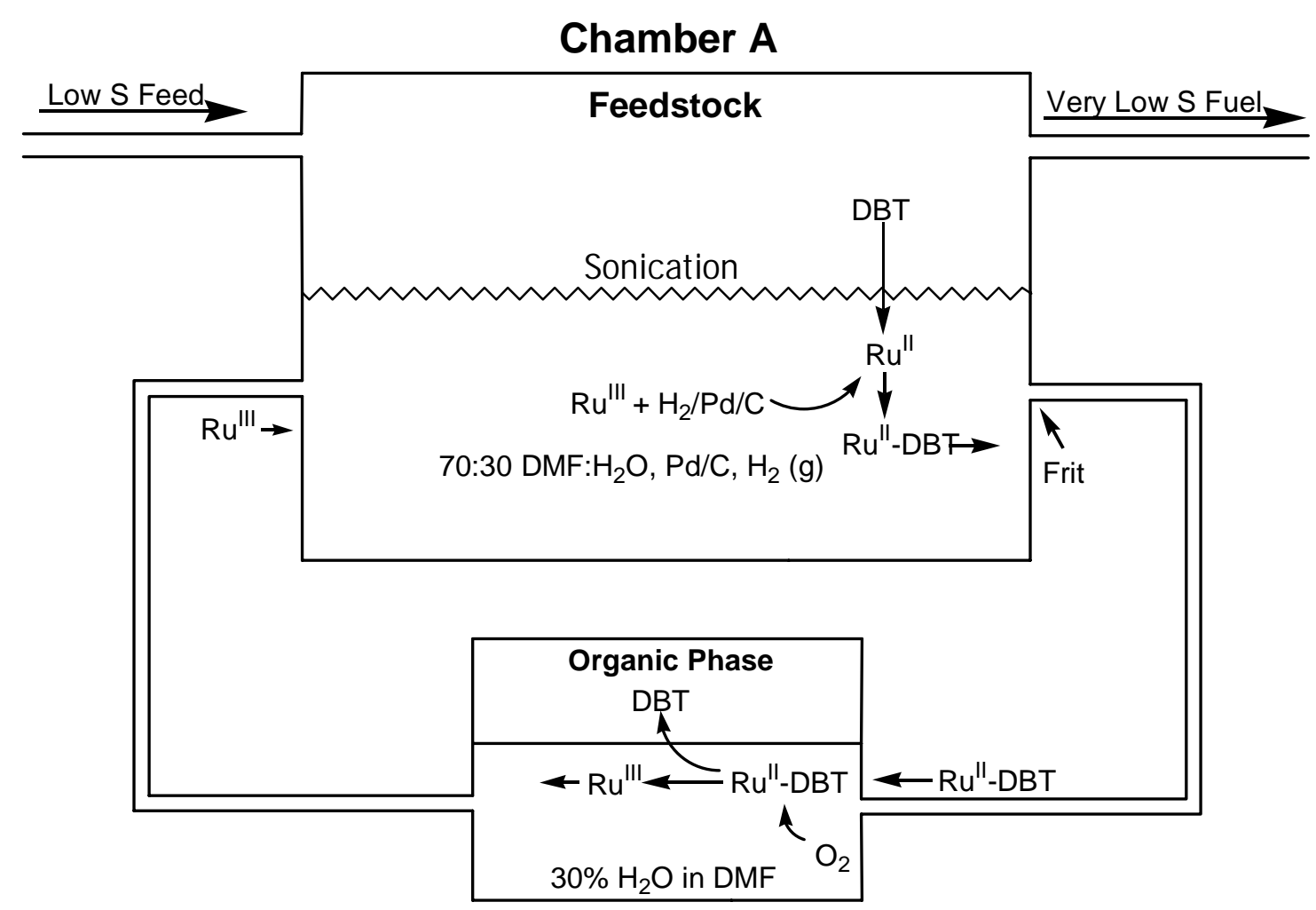

Chamber B

Scheme 2. Separator design for the removal of DBT from low-sulfur feedstocks.

$\mathrm{H}_{2} \mathrm{O}$ containing $\mathrm{Pd} / \mathrm{C}$ under bubbling $\mathrm{H}_{2}$. The top line in Scheme 3 shows that this extraction decreases the DBT level slightly to $0.035 \%$. However, when a five-fold molar excess (5x, with respect to DBT) of $\mathrm{Ru}\left(\mathrm{NH}_{3}\right)_{5}\left(\mathrm{H}_{2} \mathrm{O}\right)^{2+}$ is added to the $\mathrm{DMF} / \mathrm{H}_{2} \mathrm{O}$ phase, $32.5 \%$ of the DBT is removed from the feedstock leaving the feedstock with only $0.027 \%$ sulfur. When the amount of $\mathrm{Ru}\left(\mathrm{NH}_{3}\right)_{5}\left(\mathrm{H}_{2} \mathrm{O}\right)^{2+}$ is increased to a ten-fold molar excess (bottom line in Scheme 3), the DBT content of the feedstock phase is reduced to $0.020 \%$, which means that $50 \%$ of the DBT in the feedstock is removed.

These DBT extractions reach equilibrium within one hour at room temperature. Equilibrium constants calculated for the two extractions give an average value of $\mathrm{K}_{\mathrm{eq}}=$ 0.0108 (Scheme 4). 
Scheme 3. Extraction of DBT from Simulated Petroleum Fuel by $\left[\mathrm{Ru}\left(\mathrm{NH}_{3}\right)_{5}\left(\mathrm{H}_{2} \mathrm{O}\right)\right]\left[\mathrm{PF}_{6}\right]_{2}$ in a 70:30 DMF: $\mathrm{H}_{2} \mathrm{O}$ Mixture.

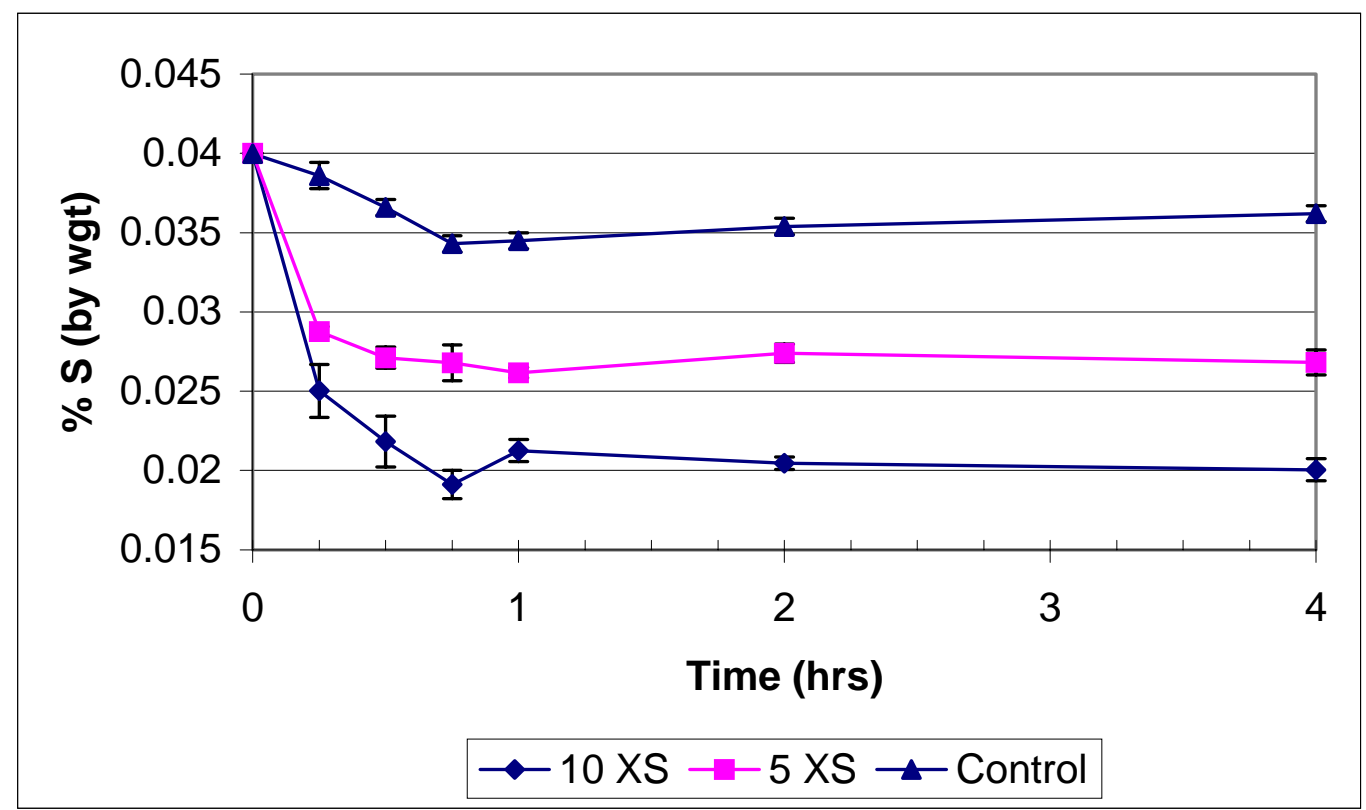

$$
\begin{gathered}
\mathrm{Ru}\left(\mathrm{NH}_{3}\right)_{5}\left(\mathrm{H}_{2} \mathrm{O}\right)^{2+}(\mathrm{aq})+\mathrm{DBT} \text { (organic) } \\
\mathrm{K}_{5 \text {-Fold Excess }}=0.111( \pm 0.004) \\
\mathrm{K}_{10 \text {-Fold Excess }}=0.105( \pm 0.008) \\
\mathrm{K}_{\text {Average }}=0.108
\end{gathered}
$$

Scheme 4. Equilibrium values for extraction process. 


\section{CONCLUSIONS}

Reducing further the sulfur content in hydrotreated petroleum feedstocks is a challenging goal. Our results reported herein make a significant contribution towards that end. We have prepared and characterized the metal complex $\mathrm{Ru}\left(\mathrm{NH}_{3}\right)_{5}\left(4,6-\mathrm{Me}_{2} \mathrm{DBT}\right)^{2+}$. On the basis of the demonstrated ability of $\mathrm{Ru}\left(\mathrm{NH}_{3}\right)_{5}\left(\mathrm{H}_{2} \mathrm{O}\right)^{2+}$ to bind DBT, we have developed a process for the removal of DBT from simulated feedstocks. These initial studies show that at least $50 \%$ of the DBT in fuel feedstocks can be removed by using this system. Moreover, the DBT can be removed from the extracted form, $\mathrm{Ru}\left(\mathrm{NH}_{3}\right)_{5}(\mathrm{DBT})^{2+}$, and $\mathrm{Ru}\left(\mathrm{NH}_{3}\right)_{5}\left(\mathrm{H}_{2} \mathrm{O}\right)^{2+}$ can be regenerated for re-use in the extractions. Each step of this process has been demonstrated in laboratory experiments. Future studies will focus on extractions of a broader range of organosulfur compounds in petroleum feedstocks. 


\section{$\underline{\text { REFERENCES }}$}

1 a) Ho, T.C. Cat. Rev. 1988, 30, 117. b) Angelici, R.J. in Encyclopedia of Inorganic Chemistry, R.B. King, Ed.; John Wiley \& Sons, New York, 1994, p. 1433. c)Kasztelan, S.; des Courieres, T.; Breysse, M. Catal. Today, 1991, 10, 433. d) Angelici, R.J. Organometallics 2001, 20, 1259.

2 Borushko, M. Fed. Regist. 2001, 66, 5001.

3 a) Satterfield, C.N., Heterogeneous Catalysis in Industrial Practice, McGraw-Hill, New York, 1991, p. 378. b) McCulloch, D.C. in Applied Industrial Catalysis; Leach, B.E., Ed.; Academic Press, New York, 1983, Vol. 1, p. 69.

4 a) Whitehurst, D.D.; Isoda, T.; Mochida, I. Adv. Catal. 1998, 42, 345. b) Gates, B.C.; Topsøe, H. Polyhedron 1997, 16, 3213. c) Topsøe, H.; Clausen, B.S.; Massoth, F.E.. Hydrotreating Catalysis Science and Technology, Springer, Berlin, 1996, p. 7.

5 Pangborn, A. B.; Giardello, M. A.; Grubbs, R. H. Rosen, R. K.; Timmers F. J. Organometallics 1996, 15, 1518.

6 Allen, A.D.; Bottomley, F.; Harris, R.O.; Reinsalu, V.P.; Senoff, C.V. Inorg. Synth. $1970,12,2$.

7 Kuehn, C.G.; Taube, H. J. Am. Chem. Soc. 1976, 98, 690.

8 a) Choi, M-G.; Angelici, R.J. Organometallics, 1991, 10, 2430. b) Choi, M-G.;

Angelici, R.J. Organometallics, 1992, 11, 3328.

9 Meyers, A.W.; Jones, W.D. Organometallics 1996, 15, 2905.

10 Shepherd, R.E.; Taube, H. Inorg. Chem. 1973, 12, 1392. 
11 Sundberg, R.J.; Bryan, R.F.; Talor, I.F. Jr.; Taube, H. J. Am. Chem. Soc. 1974, 96, 381.

12 Armor, J.N. ; Taube, H. J. Am. Chem. Soc. 1970, 92, 6170

13 a) Lim, H.S.; Barclay, D.J.; Anson, F.C. Inorg. Chem. 1972, 11, 1460. b) Baxendale,

J.H.; Rogers, R.A.; Ward, M.D. J. Chem. Soc. A. 1970, 1246.

14 Arévalo, A, Bernès, S.; García, J.J.; Maitlis, P.M. Organometallics 1999, 18, 1680.

15 Vicic, D.A.; Jones, W.D. Organometallics 1988, 17, 3411.

16 Benson, J.W.; Angelici, R.J. Organometallics 1992, 11, 922.

17 White, C.J.; Wang, T.; Jacobson, R.A.; Angelici, R.J. Organometallics 1994, 13, 4474.

18 a) Zhao, M.; Clarke, M.J. J. Bio. Inorg. Chem. 1999, 4, 318.

19 a) Evans, C.E.B.; Yap, G.P.A.; Crutchley, R.J. Inorg. Chem. 1998, 37, 6161 